\title{
Implementation of Thematic Learning Curriculum 2013; Multi Site Study at MIN 2 Kediri and MIN 1 Kediri City
}

\author{
Sri Ambarwati ${ }^{1}$ \\ ${ }^{1}$ Madrasah Ibtidaiyah Negeri (MIN) 2 Kediri \\ ${ }^{1}$ sriambarwatil6a@gmail.com
}

\begin{abstract}
This paper intends to answer the implementation of thematic learning in the 2013 curriculum. In addition, the authors examine the factors that support and obstruct the implementation of thematic learning in the 2013 curriculum. The type of research used is descriptive qualitative using interview, observation and documentation techniques. The research was conducted at 2 MIN in Kediri City. The results of the first study, Thematic Learning has a very important role in increasing students' attention, learning activities, and understanding of the material being studied, because learning is more student-centered, provides direct experience to students, the separation of subjects is not very clear, presents concepts from various Subjects in a learning process, are flexible, learning outcomes can develop according to student interests and needs. Thematic learning to be successful is carried out by taking the stages of planning, implementation, and evaluation. Second, the supporting factors include: (a) infrastructure, (b) the existence of a remedial teaching program, (c) the existence of training on the 2013 curriculum, (d) teacher creativity, (e) use of appropriate methods, (f) the existence of ice breaking in learning. meanwhile, inhibiting factors in the implementation of thematic learning in the 2013 curriculum include: (a) internal students, (b) teachers do not understand the 2013 curriculum, (c) teachers are less creative in collaborating learning methods, (d) lack of parental support, (e) less supporting infrastructure, and (f) no previous training.
\end{abstract}

Key Word: Thematic Learning, 2013 Curriculum.

\begin{abstract}
Abstrak
Tulisan ini bermaksud menjawab implementasi pembelajaran tematik pada kurikulum 2013. Di samping itu penulis menjawab faktor yang menjadi pendukung dan penghambat implementasi pembelajaran tematik pada kurikulum 2013. Jenis penelitian yang digunakan adalah deskriptif kualitatif dengan menggunakan teknik wawancara, observasi, dan dokumentasi. Penelitian dilaksanakan pada 2 MIN Kota Kediri. Hasil penelitian pertama, pembelajaran tematik memiliki peran yang sangat penting dalam meningkatkan perhatian, aktifitas belajar, dan pemahaman siswa terhadap materi yang dipelajarinya, karena pembelajaran lebih berpusat pada siswa, memberikan pengalaman langsung kepada siswa, pemisahan mata pelajaran tidak begitu jelas, menyajikan konsep dari berbagai mata pelajaran dalam suatu proses pembelajaran, bersifat fleksibel, hasil pembelajaran dapat berkembang sesuai dengan minat, dan kebutuhan siswa, pembelajaran tematik agar berhasil dengan baik dilakukan dengan menempuh tahapan perencanaan, penerapan, dan evaluasi. Kedua, Adapun faktor pendukungnya antara lain: (a) sarana prasarana, (b) adanya program
\end{abstract}


remedial teaching, (c) adanya pelatihan tentang kurikulum 2013, (d) kreatifitas guru, (e) penggunaan metode yang tepat, (f) adanya ice breaking dalam pembelajaran. Sementara, faktor penghambat dalam pelaksanaan pembelajaran tematik kurikulum 2013 antara lain: (a) internal siswa, (b) guru kurang memahami tentang kurikulum 2013, (c) guru kurang kreatif dalam mengolaborasikan metode-metode pembelajaran, (d) kurangnya dukungan orangtua, (e) sarana prasarana kurang mendukung, dan (f) tidak adanya training sebelumnya.

Kata Kunci: Kurikulum 2013, Pembelajaran Tematik.

\section{Introduction}

The tendency of thinking today is that children will learn better if the environment is created naturally. Learning will be more meaningful if children experience what they learn, not just know it. Learning that is oriented towards mastery of the material has proven to be successful in short-term memory competencies, such as success in completing exams and winning quiz competitions that only require momentary knowledge, but fail to equip children to solve long-term life problems. Children are not able to apply the knowledge they get in school to the real world in their daily lives. ${ }^{1}$

The phenomenon of the lack of cultivation of knowledge encourages the government to put more effort into improving the quality of education which is oriented towards forming believers,

${ }^{1}$ Christina Dwi Kartika Budi Utami, "Pengaruh Metode Belajar Aktif Model Pengajaran Terarah Dalam Meningkatkan Prestasi Belajar IPS Perjuangan Melawan Penjajah Pada Siswa Kelas V SDN Bringinbendo 2 Kabupaten Sidoarjo," Jurnal Refleksi Pembelajaran (JRP) 4, no. 1 (28 Februari 2019): 1422. productive, creative, innovative, and affective people who are able to contribute to the life of society, nation, state and world civilization. Given the importance of education, that education in imparting knowledge must always be considered and developed. $^{2}$

The position of a person who has knowledge as confirmed in Surah Al-Muj is: 11. The translation: “... Allah will exalt those who believe among you and those who are given several degrees of knowledge. And Allah knows best what you are doing. ${ }^{3}$ The verse about the position of a person who has this knowledge confirms that Allah swt. will raise the degree of those who have knowledge above those who believe. It is clear that the importance of knowledge is so important that Allah will elevate his position.

Seeing the urgency of an education in imparting knowledge, the government strives

2 Azyumardi Azra, Pendidikan Islam: Tradisi dan Modernisasi di tengah Tantangan Milenium III (Jakarta: Prenada Media, 2019).

3 “Al-Mujadalah - المجادلة | Qur'an Kemenag," diakses $17 \quad$ September 2020 , https://quran.kemenag.go.id/sura/58. 
for educational advancement. One of the government's efforts is updating the new curriculum with the aim of improving the system, process and evaluation in education. The curriculum as a document serves as a guide for educators. This document looks at the ability of educators to understand content standards and compile a syllabus of the subjects they care for. This is followed by the ability of educators to prepare learning plans which include learning service strategies that are thought to be able to make the learning process more innovative, creative, and interesting. While the curriculum as implementation is the realization of the guidelines in the form of learning activities. ${ }^{4}$

The change in the 2006 curriculum to the 2013 curriculum is basically a change in mindset, it can be said that it is a change in the teaching culture of teachers in implementing education in schools. Thus, to support the implementation of the 2013 curriculum in accordance with the desired design, it is necessary to change the teaching strategy of teachers in relation to professionalism in implementing the curriculum. $^{5}$

\footnotetext{
4 Mursal Aziz, "Implementasi Kebijakan Majelis Pendidikan Al-Washliyah Dalam Pengembangan Kurikulum Madrasah Aliyah AlWashliyah Di Sumatera Utara" (Masters, Universitas Islam Negeri Sumatera Utara, 2019), http://repository.uinsu.ac.id/8600/.

5 A. Masruhin, "Implementasi Kurikulum 2013 Di Madrasah Ibtidaiyah Kabupaten Semarang," Edification Journal 3, no. 1 (4 Agustus 2020): 85109, https://doi.org/10.37092/ej.v3i1.220; Abdullah K Jurnal Intelektual: Jurnal Pendidikan dan Studi Keislaman

Volume 10, Nomor 2, Agustus 2020

dan Fahmiah Akilah, "Relevansi Kurikulum 2013 Dengan Pembelajaran Pai Dalam Upaya Pembentukan Karakter Peserta Didik," Adaara: Jurnal Manajemen Pendidikan Islam 10, no. 1 (28 Februari 2020): 11-23, https://doi.org/10.35673/ajmpi.v10i1.853; Hamdani, "Problematika Guru Pendidikan Agama Islam Dalam Penerapan Kurikulum 2013 (K-13) Di Smp Negeri 1 Kepahiang" (other, IAIN BENGKULU, 2020), http://repository.iainbengkulu.ac.id/4520/.
}

The purpose of the 2013 curriculum itself is expressed in Permendikbud No.67 of 2013: The 2013 curriculum aims to prepare Indonesian people to have the ability to live as individuals and citizens who are faithful, productive, creative, innovative, and affective and are able to contribute to the life of society, nation, state, and world civilization.

The goal of the 2013 curriculum emphasizes that learning must impart knowledge into all domains, including: cognitive, affective, psychomotor. In the cognitive domain (knowledge) is the initial level of the realm where students are in a degree of knowing, so this domain is still weak. Then the next level is the affective or the realm of attitude, after students know it will show an attitude in accordance with the character that has been implanted in this learning. The third domain is psychomotor (action), when the attitude arises, then the students must apply it in action. These are the learning objectives expected by the 2013 Curriculum.

Forming intelligent, creative and innovative students so that they are not only aware but also implemented in daily actions 
as citizens. So that learning must be one unit, holistic. Integrated as a whole and not separately in one theme. ${ }^{6}$ The purpose of this curriculum is in line with the function of national education, which basically forms a dignified national character and civilization in order to educate the nation's life. As illustrated in Law No. 20 of 2003 concerning the National Education System Article 3: "National education has the function of developing capabilities and shaping dignified national character and civilization in order to educate the nation's life, aiming at developing the potential of students to become human beings who believe and fear God Almighty, have noble character, are healthy, knowledgeable, capable, creative independently, and become democratic and responsible citizens. The 2013 curriculum is an integrated curriculum that allows students to learn both individually and classically. They actively explore and discover concepts and principles in a holistic, meaningful and authentic manner. Through these considerations, various views and opinions on integrated learning. But all of them emphasize delivering meaningful lessons by involving students in the learning process.

Based on the learning process, the thematic 2013 curriculum uses a scientific (scientific) approach which consists of the process of observing, asking, experimenting,

${ }^{6}$ Azra, Pendidikan Islam.

associating, communicating. It is hoped that in the learning process children can learn naturally, experience directly so that the absorbed material becomes more meaningful and sticks to the child for a long time.

One of the characters of thematic learning is authentic learning, so the assessment in this learning must be authentic. Authentic assessment or authentic assessment has strong relevance to a scientific approach in accordance with the demands of the 2013 curriculum. $^{7}$

The definition of authentic assessment is defined as stated in Permendikbud No. 66 of 2013 concerning the standard of assessment "Authentic assessment is an assessment that is carried out comprehensively to assess starting from the input (input), process, and output (output) learning." Authentic assessment is in accordance with the principles of assessment according to the BSNP (National Education Standards Agency), which is comprehensive and integrated with learning. Comprehensive means that the assessment of learning outcomes that is carried out must cover various aspects of the competence to be assessed and consist of cognitive, affective, and psychomotor domains. Whereas

${ }^{7}$ Latifatul Muyasaroh, "Implementasi Penilaian Autentik Kelas 1 Pada Pembelajaran Tematik, Tema: 4 Keluargaku di SD Negeri 01 Purwanegara Kec. Purwokerto Utara Kab. Banyumas" (skripsi, IAIN Purwokerto, 2019), http://repository.iainpurwokerto.ac.id/5207/. 
integrated, namely in assessing learning reject failures; (5). They learn effectively activities must consider cognitive, affective, when they are satisfied with the situation; and psychomotor, so that the assessment is not only carried out after students have completed certain subjects, but also in the learning process. ${ }^{8}$

Authentic assessment must be able to describe what attitudes, skills, and knowledge students already have or don't have, how they apply their knowledge, in what cases they have or have not been able to apply learning acquisition and so on. The implementation of this thematic learning is relevant to be applied at the MI/SD level, seeing the character of MI/SD children who describe joy. ${ }^{9}$ The characteristics of primary school age children in general as stated by Basset, Jacka, and Logan (1983) are as follows: (1). They are naturally curious and interested in the world around them; (2). They like to play and are more happy/cheerful; (3). They like to organize themselves to handle things, explore a situation and try new ventures; (4). They are usually thrilled and driven to achieve just as they hate to experience dissatisfaction and

8 Dewi Puspita Ningsih dan Izza Maulida, "Implementasi Kurikulum 2013 Dalam Membentuk Karakter Siswa Pada Pembelajaran Tematik Integratif Kelas IV Di SDN I Gapuk," JISIP (Jurnal Ilmu Sosial Dan Pendidikan) 3, no. 1 (13 Maret 2019), https://doi.org/10.36312/jisip.v3i1.988.

9 Wina Calista, "Pelaksanaan Penilaian Autentik Kurikulum 2013 Pada Pembelajaran Tematik Tema Sumber Energi Kelas III Di MI Negeri 1 Yogyakarta," MODELING: Jurnal Program Studi PGMI 6, no. 2 (26 September 2019): 196-203, https://doi.org/10.36835/modeling.v6i2.450. Jurnal Intelektual: Jurnal Pendidikan dan Studi Keislaman end (6). They learn by working, observing, taking the initiative to teach other children. ${ }^{10}$

Based on the character of the MI/SD children, the thematic learning is very relevant to be applied considering the fun and contextual learning. As the Prophet said. about the delivery method in learning which means "From Anas bin Malik Radhiyallahu 'Anhu, From the Prophet Salallahu' alaihi wa sallam, he said," Make it easy and don't make it difficult. Give good news and don't make people run. " (HR Bukhari: 69)

The hadith from Anas bin Malik Radhiyallahu 'Anhu, from the Prophet sallallaahu' alaihi wa sallam, explains that the learning process must be made easy and enjoyable so that students are not psychologically depressed and do not feel bored with the atmosphere in class, as well as what the teacher teaches such as learning thematic. Learning must also use appropriate methods adapted to the situation and conditions, especially taking into account the circumstances of the person who will learn (students).. ${ }^{11}$

10 Rima Trianingsih, "Pengantar Praktik Mendidik Anak Usia Sekolah Dasar," Al Ibtida: Jurnal Pendidikan Guru MI 3, no. 2 (29 Oktober 2016): 197-211,

https://doi.org/10.24235/al.ibtida.snj.v3i2.880.

11 Muhammad Norazmi, "Pengaruh Model Pembelajaran Role Playing Terhadap Hasil Belajar PKn Materi Keputusan Bersama Kelas V Di Sekolah Pada SD Negeri 101870 Desa Sena." (skripsi, 
In addition to seeing the character of MI/SD children, the reason for applying thematic learning also looks at the problems of the curriculum that has been applied so far. The KTSP curriculum that was implemented so far before the 2013 curriculum was implemented picked up problems in terms of subjects that were too dense, too much material was not concrete, so it was too broad and difficult to understand by students, especially in everyday life. In addition, the pre-2013 curriculum was also less sensitive and responsive to social changes that occurred at the local, national and global levels. ${ }^{12}$

The learning that has occurred so far does not reflect meaningfulness, because it is only result oriented without considering the process. Because learning adjusts to the curriculum used and the curriculum before 2013 is only result-oriented so that learning does not see a student naturally, even though evaluation also needs to pay attention to the process and results.

With the implementation of thematic learning curriculum 2013, students are expected to be able to learn in a more meaningful way naturally because every stage in the learning process is considered in

Universitas Islam Negeri Sumatera Utara, 2019), http://repository.uinsu.ac.id/6135/.

12 Herman Zaini, "Karakteristik Kurikulum 2013 Dan Kurikulum Tingkat Satuan Pendidikan (KTSP)," El-Idare: Jurnal Manajemen Pendidikan Islam 1, no. 01 (2015): 15-31.

the evaluation system, so that it is not only in the results of the learning process. ${ }^{13}$ So that it can be said that the thematic learning of the 2013 curriculum complements the previous curriculum.

The 2013 curriculum is different from the previous curriculum, because it is natural that doubts arise in its implementation. This research wants to reaffirm that the 2013 Curriculum, with all its shortcomings and strengths, is a momentum worthy of note in the history of education in this country.

From the problems described above, the researchers are interested in examining these problems more deeply through field research research entitled "Implementation of Thematic Learning Curriculum 2013: MultiSite Study at MIN 2 Kediri and MIN 1 Kota Kediri" From the description of the research context above, the researcher limits the problem. and used as a formulation of the problem as follows: (1) Implementation of thematic learning Curriculum 2013 for grade 1 students with the theme "myself" in MIN 2 Kediri and MIN 1 Kediri City. (2) Supporting factors and inhibiting factors in the implementation of thematic learning Curriculum 2013 in grade 1 students with the

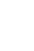

\footnotetext{
13 A. Jauhar Fuad dan Manu Winarsih, "Peningkatan Prestasi Belajar Dengan Metode Bermain Peran Pada Tema Kegiatan Jual Beli," PROCEEDING: The Annual International Conference on Islamic Education 3, no. 1 (26 Februari 2018): 8799.
} 
theme "myself" in MIN 2 Kediri and MIN 1 Kediri City.

\section{Research Method}

This study uses a qualitativedescriptive analytical research method with inductive logic, namely research aimed at describing the data that has been collected in the form of words, pictures of events, thoughts of people individually or in groups. The locations in this study represent two public Islamic schools in Kediri City and Kediri Regency, namely MIN 2 Kediri and MIN 1 Kediri City. This type of research that has been formulated in the formulation of the problem will be used to determine how the implementation of thematic learning Curriculum 2013 and the factors that support and hinder it in students. The data analysis method used by the writer is descriptive analysis, the writer describes the data that has been obtained systematically from interviews, field notes, and documentation.

\section{Result and Discussion}

Analysis of 2013 Curriculum Implementation in MIN 2 Kediri and MIN

\section{Kediri City}

The 2013 curriculum is a complement to the previous curriculum. Where the implementation is thematic and authentic. This is intended so that the subjects are not separated, linking fields of study to one another. So that learning becomes more holistic. $^{14}$

Teaching and Learning Activities $(\mathrm{KBM})$ in MIN 2 Kediri and MIN 1 Kediri City want to unite faith, piety, and knowledge that is constructed through holistic learning in thematic by paying attention to the contextual of everyday life. That way the school's vision and mission that was announced can be achieved properly.

Imtaq is a business that is full of values, beliefs, understandings, attitudes, feelings and behaviors that come from the Koran and hadith. Meanwhile, science and technology is a combination of science (science) and technology. The IMTAQ and Science and Technology Curriculum Model is an integrated curriculum that can build knowledge, attitudes and skills of the output of Islamic education institutions in integrating science and technology and Imtaq which are given Islamic nuances for general subjects of Islamic educational institutions. ${ }^{15}$

So, the implementation of the 2013 curriculum at MIN 2 Kediri and MIN 1 Kota Kediri is still colored with the IMTAq and science and technology curriculum. Where the curriculum is integrated with science and technology and religious values.

${ }^{14}$ Sutiah, Pengembangan Kurikulum PAI Teori Dan Aplikasinya (Malang: NLC, 2020).

15 Ilham Ilham, "Sinergisitas Pendidikan Is lam: Model Sinergisitas Lembaga Pendidikan Islam Di Indonesia," TAJDID: Jurnal Pemikiran Keislaman Dan Kemanusiaan 3, no. 2 (4 Oktober 2019): 236-58. 
Thematic learning is learning a learning approach that is based on the integration of subjects centered on themes within a certain time span as determined. The predetermined themes must be delivered within the specified time. In its implementation in MIN 2 Kediri and MIN 1 Kediri City thematic learning is arranged in one week of six lessons, and one meeting can reach 1-3 lessons. The stages in thematic learning are:

\section{a. Learning Planning}

Like learning in general, thematic learning in preparation also needs to make all learning programs such as: prota, promes, syllabus, lesson plans. Implementing the program is basically implementing programs that have been arranged in the teaching and learning process in the classroom. This means that the successful implementation of learning is highly dependent on the quality of the lesson plans that have been prepared, especially the syllabus and lesson plans.

The semester program is an action plan that will be carried out by the teacher within one semester. The annual program is an action plan that will be carried out by the teacher within one year.

A syllabus is a written design developed by the teacher as a learning plan for one semester that is used by the teacher as the professional responsibility of educators to the institution, peers, students, and the community. After compiling the series above, an RPP is made based on themes, sub-themes, and lessons. In accordance with the applicable rules, this RPP is made in the applicable format. ${ }^{16}$

\section{b. Implementation of Learning}

Before starting the learning process, MIN 2 Kediri and MIN 1 Kota Kediri always familiarize themselves with prayer and memorizing short letters in the Koran. This really reflects that Islamic religious characters are the foundation of all existing characters. Even in MIN 2 Kediri, the practice of duha prayer has started to be implemented. Habituation from an early age is the key to instilling character values. This is what distinguishes religious character education from other characters. That a religious character does not have to start with knowing, followed by feeling, and then doing later. But starting from doing, it continues with knowing, and finally feeling. The Javanese philosophy states "ajining tresno soko kulino", which means that to love good habits, one has to get used to it from

16 Pariang Sonang Siregar dan Rindi Genesa Hatika, Ayo Latihan Mengajar:: Implementasi Kurikulum 2013 Di Sekolah Dasar (Peerteaching Dan Microteaching) (Deepublish, 2019); Sugeng Listyo Prabowo, Perencanaan pembelajaran pada bidang studi, bidang studi tematik, muatan lokal, kecakapan hidup, bimbingan dan konseling (Malang: UIN-Maliki Press, 2010), http://repository.uin-malang.ac.id/1616/. 
an early age without knowing whether it is good for him or not.

The stages in a comprehensive scientific approach as stipulated in Permendikbud Number 54 of 2014 include: observing, asking questions, gathering information, reasoning, communicating. The core activities use models, methods, media and learning resources that are tailored to the characteristics of students and subjects. ${ }^{17}$

c. Learning Evaluation

Authentic assessment becomes the basis for evaluating learning at MIN 2 Kediri and MIN 1 Kediri City. Although this authentic by a number of teachers, with the existence of several training activities and workshops held by schools and assessment is considered somewhat complicated the government, teachers are starting to understand and get used to it. There are several stages in presenting reports on the learning outcomes of the 2013 curriculum thematic learning at MIN 2 Kediri and MIN 1 Kediri, including: descriptive (qualitative), quantitative, habituation. This descriptive assessment report card is in the form of a detailed explanation of the conversion results from the value in the form of numbers. Then a

17 Alfiyan Yusuf, "Metode Pembelajaran Saintifik Dalam Pengajaran PAI Kelas XI di SMA Windu Wacana Kota Cirebon" (skripsi, Cirebon, IAIBBC, 2020), http://repository.bungabangs acirebon.ac.id/xmlui/hand le/123456789/409. quantitative report card is a student report card in the form of numbers before being converted into a descriptive report. Habituation report cards are students' learning reports in the form of teacher observations in the learning process which includes KI- (spiritual) and KI-2 (attitudes). ${ }^{18}$

\section{Analysis of Supporting and Inhibiting}

Factors for the Implementation of 2013

\section{Curriculum Learning}

a. Supporting Factors for Learning Curriculum 2013 at MIN 2 Kediri and MIN 1 Kediri City

Some of the supporting and inhibiting factors that occur in MIN 2 Kediri and MIN 1 Kediri City are as follows:

1) Infrastructure

Thematic learning essentially emphasizes students both individually and in groups to actively seek, explore and find concepts holistically and authentically. Therefore, the implementation requires a variety of learning facilities and infrastructure.

Facilities and infrastructure in the learning environment at MIN 1 Kediri City are in

${ }^{18}$ Ina Magdalena dkk., "Evaluasi Pembelajaran Tematik Dengan Penilaian Autentik Di SDN Pasar Baru 1 Kota Tangerang," Jurnal Halaqah 2, no. 3 (31 Juli 2020): 306-14, https://doi.org/10.5281/zenodo.3911958; Mimi Musmiroh Idris dan Abas Asyafah, "Penilaian Autentik Dalam Pembelajaran Pendidikan Agama Islam," Jurnal Kajian Peradaban Islam 3, no. 1 (16 Januari 2020): https://doi.org/10.47076/jkpis.v3i1.36. 
accordance with the SNP regulated in the PP. Number 32 of 2013 concerning standard facilities and infrastructure. Standard Facilities and Infrastructure are criteria regarding study rooms, places for sports, places of worship, libraries, laboratories, workshops, playgrounds, places for creation and recreation as well as other learning resources, which are needed to support the learning process, including the use of information and communication technology.

Adequate facilities and infrastructure will support a learning that is carried out properly. ${ }^{19}$ If the facilities in the school are not supportive, it will hamper the implementation of learning, especially in the 2013 curriculum thematic learning.

2) The existence of a Remedial Teaching Program

Remedial Teaching is held on the basis that the curriculum has a core program or a minimum program that students must master. Students are expected to achieve a minimum standard of knowledge and understanding at each stage of the learning delivered. In addition, to enrich knowledge in the fields of employment, artistic creation, and culture, elective

19 Muhammad Yamin, Tobari Tobari, dan Missriani Missriani, "Manajemen Sarana Dan Prasarana Dalam Meningkatkan Hasil Belajar Siswa Di SD IT Kautsar Ilmi Tanjung Raja," Jurnal Intelektualita: Keislaman, Sosial Dan Sains 9, no. 1 (11 April 2020):

$139-48$, programs are provided. In that case, students may need remedial teaching, especially in the field of career advancement in the classroom. ${ }^{20}$

Teachers play a very important role in remedial education as an effort to overcome learning difficulties experienced by students, if it is not carried out properly, it will certainly have a negative impact on human resource outcomes in the sense that education fails. So that it will be a direct bad effect on society. So that remedial education is also important to be applied in education.

As is the case with the implementation of this thematic-based 2013 curriculum, the more complex assessments make a number of teachers more extra in observing each process and learning stage. Students who have not reached KKM do not mean they have failed but it could be that in one of the stages of learning they are not good at mastering it, from which the teacher knows the weaknesses of students and can implement a remedial education program that is focused on the stage where students cannot master it.

20 Lutfia Antani Hanjani, “Analisis Program Remedial dalam Mencapai Kriteria Ketuntasan Minimal Ulangan Harian Bahasa Jepang di SMA Kemala Bhayangkari 1 Surabaya," HIKARI 4, no. 2 (31 Juli 2020), https://jurnalmahas is wa.unesa.ac.id/index.php/hikari/a rticle/view/35802; M. Muizuddin, "Remidial Teaching Sebagai Usaha Pendidik Mengatasi Kesulitan Belajar Siswa," MIYAH : Jurnal Studi Islam 12, no. 2 (12 Mei 2019): 87-113. 
3) The existence of training on the 2013 curriculum

A program that has a purpose should be prepared with all careful planning. As is the case with implementing the 2013 curriculum, which in every element has undergone changes from the previous curriculum, if this is implemented immediately without any preparation there is a concern that things will be lacking. So that to avoid this from happening, some of the training prior to the implementation of the 2013 curriculum implements the need for programs such as workshops, trainings from the center, comprehensive outreach from the government, and others. ${ }^{21}$

4) Teacher creativity

Teacher creativity in teaching is certainly something that must be recorded in the learning process. $^{22}$ From a teaching point of view, delivering material certainly really depends on the strategy that the teacher has prepared so that the material can be conveyed properly. Especially with the 2013 curriculum which is scientifically based, which includes several scientific stages in learning. So

21 Sherlyane Hendri dkk., "Pelatihan Penilaian Otentik Dan Penggunaan Aplikasi Penilaian Kurikulum 2013 Untuk Sekolah Dasar," Jurnal Halaqah 1, no. 4 (31 Oktober 2019): 446-59, https://doi.org/10.5281/zenodo.3526816.

22 Styorini Danar, "Manajemen Pengembangan Guru Kreatif Seksi Pendidikan Madrasah Di Kantor Kementerian Agama Kabupaten Klaten, Tahun 2017" (masters, IAIN Surakarta, 2017), http://eprints.iainsurakarta.ac.id/990/. that students can carry out learning activities like a scientist who finds his own theory.

Teachers must be creative in linking themes to the surrounding environment so that learning becomes complete. In addition to contextualizing the material, the teacher is also required to be creative in collaborating the methods to be used and adjusted in the themes to be delivered, so that learning can take place in a varied and not monotonous manner. Without this creativity thematic learning will not be carried out well.

5) Use of appropriate methods

The variety of methods used in learning will determine whether learning can run well or not, because methods that attract students' attention and activity will make lessons more enjoyable and not monotonous. $^{23}$ Thematic learning should not only use a single method, but collaborate with several methods, so that learning becomes interesting and makes it easier for teachers to deliver material to students. Because thematic learning is rather difficult to convey using a single method, it needs variations so that themes are easier to link and contextualize.

6) The existence of Ice Breaking in Learning

23 A. Jauhar Fuad, "Storytelling Variations and Student Writing Ability in Madrasah Ibtidaiyah," MODELING: Jurnal Program Studi PGMI 6, no. 1 (13 Maret 2019): 13-30. 
In learning activities, fun activities that the 2013 curriculum can be mapped as can attract students' attention should be follows:

carried out, such as methods of singing, playing, clapping, or others. This makes students not get bored quickly in learning, and students enjoy learning more without feeling boredom or fatigue.

Ice Breaking are techniques used in a training forum, seminar, meeting, teaching and learning activity, or meeting to break the ice, the boredom that occurs in the forum and the audience or participants are concentrated again. Benefits of an ice breaker:

1) There is an optimal or even maximum information delivery and absorption process.

2) The growing motivation of trainers/teachers and audience/participants to learn in the teaching and learning process

3) Strengthening the relationship between trainers/teachers and audience/learning participants. $^{24}$

b. Inhibiting Factors for Learning Curriculum 2013 at MIN 2 Kediri and MIN 1 Kediri City

Meanwhile, the inhibiting factors in the implementation of thematic learning in

24 Usman Usman, "Pemenang Di Atas Panggung Melalui Mahir Public Speaking," Komunikasiana: Journal of Communication Studies 1, no. 1 $(30$ Oktober 2018),
1) Internal Students

From internal factors, namely students. This is more about the readiness of students in learning. Students need to be prepared mentally and physically in receiving learning material. if students themselves are not ready to accept learning, this can hinder learning. Teachers need to prepare students' conditions well, as initial, core and learning activities. as much as possible the condition of students is always ready and on in receiving learning.

2) Teachers do not understand the 2013 curriculum

If in the implementation of the 2013 curriculum the teacher does not understand, then the learning will not be carried out properly. Teachers must be active both independently and in groups to explore as much detail as possible about the 2013 curriculum changes. By fully understanding it, of course the learning that is implemented will be easy to implement both in the classroom and outside.

3) Teachers are less creative in collaborating learning methods

Learning is less interesting due to the less varied and monotonous methods applied.

This requires the creativity of a teacher in https://doi.org/10.24014/kjcs.v 1i1.6286. 
varying the methods to be applied. Suppose the lecture method is combined with the method of singing and question and answer and interspersed with several games related to the material of course.

4) Lack of Parental Support

Another factor that hinders the application of thematic learning is the lack of support from parents. In the thematic learning of the 2013 curriculum, there is a need for cooperation from parents/guardians of students. Because this thematic learning indirectly involves parents, in the learning that takes place, of course there are follow-up activities carried out with parents at home. So that this becomes the teacher's special report about student activities at home.

5) Less Supporting Infrastructure

Infrastructure in a narrow sense such as in the classroom, and also infrastructure in a broad sense, namely in the student learning environment is something that is urgent and very much needed in learning. If it is limited and does not fulfill it, then this becomes an obstacle to learning thematic curriculum 2013.

Thematic learning in the 2013 curriculum which is scientifically based demands contextual learning, so that students no longer receive abstract learning but intuition is real in everyday life. In line with this, it is necessary to have supporting facilities and infrastructure both in IT and traditional terms.

6) Absence of previous training Training/training is important to be implemented and implemented before the 2013 curriculum is applied. Both supervisors, school principals and their staff, teachers must attend training as an initial provision of knowledge before implementing it. This is the starting point for the success of the 2013 curriculum, if there is no previous training, it will certainly be difficult in its implementation, both from teachers and schools.

The training can be carried out by the government and schools/related institutions in general or independently. So that teachers get initial knowledge about aspects of the 2013 curriculum. So that it will be easier to implement and can run as expected.

\section{Conclusion}

After doing research at MIN 2 Kediri and MIN 1 Kediri City and based on the formulation of the problem that the author has conveyed, the author can draw the following conclusions:

1. Implementation of thematic learning Curriculum 2013 for grade 1 students with 
the theme "myself' in MIN 2 Kediri and MIN 1 Kota Kediri.

The implementation of the 2013 curriculum at MIN 2 Kediri and MIN 1 in Kediri City continues to be colored with the IMTAq and science and technology curricula. Where the curriculum is integrated with science and technology and religious values. Thematic learning has a very important role in increasing students' attention, learning activities, and understanding of the material being studied, because learning is more studentcentered, provides direct experience to students, the separation of subjects is not very clear, presents the concepts of various subjects in a the learning process, is flexible, learning outcomes can develop according to the interests and needs of students, thematic learning to be successful is done by taking the stages of planning, implementing, and evaluating The stages in Thematic learning are: (a) Learning Planning, Thematic learning in preparation also needs to make all learning programs such as: prota, promes, syllabus, lesson plans; (b) Implementation of Learning, The stages in a comprehensive scientific approach consist of observing, asking, gathering information, reasoning, communicating. The core activities use models, methods, media and learning resources that are tailored to the characteristics of students and subjects $^{25}$; end (c) Learning Evaluation, Authentic assessment becomes the basis for evaluating learning at MIN 2 Kediri and MIN 1 Kediri City. There are several stages in presenting reports on the learning outcomes of the 2013 curriculum thematic learning at MIN 2 Kediri and MIN 1 Kediri, including: descriptive (qualitative), quantitative, habituation. This descriptive assessment report card is in the form of a detailed explanation of the conversion results from the value in the form of numbers. Then a quantitative report card is a student report card in the form of numbers before being converted into a descriptive report. And habituation report cards are students' learning reports in the form of teacher observations in the learning process which includes KI- (spiritual) and KI-2 (attitudes).

2. Supporting factors and inhibiting factors in the implementation of thematic learning Curriculum 2013 in grade 1 students with the theme "myself" in MIN 2 Kediri and MIN 1 Kediri City.

25 Hilyana Diana dan A. Jauhar Fuad, "Pemanfaatan Sarana Macromedia Flash Dalam Pembelajaran Fiqih Di Kelas V Madrasah Ibtidaiyah Ainul Huda Juwet Ngronggot Nganjuk," Jurnal Intelektual: Jurnal Pendidikan Dan Studi Keislaman 9, no. 3 (30 Desember 2019): 311-24, https://doi.org/10.33367/ji.v9i3.1029. 
In the implementation of thematic learning Curriculum 2013 in MIN 2 Kediri and MIN 1 Kediri City, there are supporting and inhibiting factors in its implementation. The supporting factors are: (a). Infrastructure, (b). The existence of a Remedial Teaching Program, (c). The existence of training on the 2013 curriculum, (d). Teacher Creativity, (e). Use the right method, (f). The existence of Ice Breaking in Learning.

Meanwhile, the inhibiting factors in implementing thematic learning curriculum 2013 at MIN 2 Kediri and MIN 1 Kediri City are: (a). Internal Student, (b). Teachers do not understand about the 2013 curriculum, (c). Teachers are less creative in collaborating learning methods, (d) Lack of Parental Support, (e). Less Supporting Infrastructure, end (f). No previous training.

\section{Bibliography}

Abdullah K, dan Fahmiah Akilah. "Relevansi Kurikulum $2013 \quad$ Dengan Pembelajaran Pai Dalam Upaya Pembentukan Karakter Peserta Didik." Adaara: Jurnal Manajemen Pendidikan Islam 10, no. 1 (28 Februari 2020): 11-23. https://doi.org/10.35673/ajmpi.v10i1. 853.

“Al-Mujadalah - المجادلة | Qur'an Kemenag." Diakses 17 September 2020. https://quran.kemenag. go.id/sura/58.

Aziz, Mursal. "Implementasi Kebijakan Majelis Pendidikan Al-Washliyah Dalam Pengembangan Kurikulum Madrasah Aliyah Al-Washliyah Di
Sumatera Utara." Masters, Universitas Islam Negeri Sumatera Utara, 2019. http://repository.uinsu.ac.id/8600/.

Azra, Azyumardi. Pendidikan Islam: Tradisi dan Modernisasi di tengah Tantangan Milenium III. Jakarta: Prenada Media, 2019.

Calista, Wina. 'Pelaksanaan Penilaian Autentik Kurikulum 2013 Pada Pembelajaran Tematik Tema Sumber Energi Kelas III Di MI Negeri 1 Yogyakarta." MODELING: Jurnal Program Studi PGMI 6, no. 2 (26 September 2019): 196-203. https://doi.org/10.36835/modeling.v6i 2.450 .

Danar, Styorini. "Manajemen Pengembangan Guru Kreatif Seksi Pendidikan Madrasah Di Kantor Kementerian Agama Kabupaten Klaten, Tahun 2017." Masters, IAIN Surakarta, $2017 . \quad$ http $/ /$ eprints.iainsurakarta.ac.id/990/.

Diana, Hilyana, dan A. Jauhar Fuad. "Pemanfaatan Sarana Macromedia Flash Dalam Pembelajaran Fiqih Di Kelas V Madrasah Ibtidaiyah Ainul Huda Juwet Ngronggot Nganjuk." Jurnal Intelektual: Jurnal Pendidikan Dan Studi Keislaman 9, no. 3 (30 Desember 2019): 311-24. https://doi.org/10.33367/ji.v9i3.1029.

Fuad, A. Jauhar. "Storytelling Variations and Student Writing Ability in Madrasah Ibtidaiyah." MODELING: Jurnal Program Studi PGMI 6, no. 1 (13 Maret 2019): 13-30.

Fuad, A. Jauhar, dan Manu Winarsih. "Peningkatan Prestasi Belajar Dengan Metode Bermain Peran Pada Tema Kegiatan Jual Beli." PROCEEDING: The Annual International Conference on Islamic Education 3, no. 1 (26 Februari 2018): 87-99.

Hamdani. "Problematika Guru Pendidikan Agama Islam Dalam Penerapan Kurikulum 2013 (K-13) Di Smp Negeri 1 Kepahiang." Other, IAIN BENGKULU, 2020. 
http://repository.iainbengkulu.ac.id/4 $520 /$.

Hanjani, Lutfia Antani. "Analisis Program Remedial dalam Mencapai Kriteria Ketuntasan Minimal Ulangan Harian Bahasa Jepang di SMA Kemala Bhayangkari 1 Surabaya." HIKARI 4, no. 2 (31 Juli 2020). https:/jurnalmahasiswa.unesa.ac.id/in dex.php/hikari/article/view/35802.

Hatika, Pariang Sonang Siregar dan Rindi Genesa. Ayo Latihan Mengajar:: Implementasi Kurikulum 2013 Di Sekolah Dasar (Peerteaching Dan Microteaching). Deepublish, 2019.

Hendri, Sherlyane, Yullys Helsa, Yesi Anita, dan Ary Kiswanto Kenedi. "Pelatihan Penilaian Otentik Dan Penggunaan Aplikasi Penilaian Kurikulum 2013 Untuk Sekolah Dasar.” Jurnal Halaqah 1, no. 4 (31 Oktober 2019): 446-59.

https://doi.org/10.5281/zenodo.35268 16.

Idris, Mimi Musmiroh, dan Abas Asyafah. "Penilaian Autentik Dalam Pembelajaran Pendidikan Agama Islam." Jurnal Kajian Peradaban Islam 3, no. 1 (16 Januari 2020): 1-9. https://doi.org/10.47076/jkpis.v3i1.36

Ilham, Ilham. "Sinergisitas Pendidikan Islam: Model Sinergisitas Lembaga Pendidikan Islam Di Indonesia." TAJDID: Jurnal Pemikiran Keislaman Dan Kemanusiaan 3, no. 2 (4 Oktober 2019): 236-58.

Magdalena, Ina, Anggun Mila Banowati, Reni Safitri, dan Eka Nurwahyuningsih. "Evaluasi Pembelajaran Tematik Dengan Penilaian Autentik Di SDN Pasar Baru 1 Kota Tangerang." Jurnal Halaqah 2, no. 3 (31 Juli 2020): 30614. https://oi.org/10.5281/zenodo.39119 58.

Masruhin, A. "Implementasi Kurikulum 2013 Di Madrasah Ibtidaiyah Kabupaten Semarang." Edification
Journal 3, no. 1 (4 Agustus 2020): 85-109. https://doi.org/10.37092/ej.v3i1.220.

Muizuddin, M. "Remidial Teaching Sebagai Usaha Pendidik Mengatasi Kesulitan Belajar Siswa." MIYAH : Jurnal Studi Islam 12, no. 2 (12 Mei 2019): 87113.

Muyasaroh, Latifatul. "Implementasi Penilaian Autentik Kelas 1 Pada Pembelajaran Tematik, Tema: 4 Keluargaku di SD Negeri 01 Purwanegara Kec. Purwokerto Utara Kab. Banyumas." Skripsi, IAIN Purwokerto, 2019. http://repository.iainpurwokerto.ac.id/ $5207 /$.

Ningsih, Dewi Puspita, dan Izza Maulida. "Implementasi Kurikulum 2013 Dalam Membentuk Karakter Siswa Pada Pembelajaran Tematik Integratif Kelas IV Di SDN I Gapuk." JISIP (Jurnal Ilmu Sosial Dan Pendidikan) 3, no. 1 (13 Maret 2019). https://doi.org/10.36312/jisip.v3i1.98 8.

Norazmi, Muhammad. 'Pengaruh Model Pembelajaran Role Playing Terhadap Hasil Belajar PKn Materi Keputusan Bersama Kelas V Di Sekolah Pada SD Negeri 101870 Desa Sena." Skripsi, Universitas Islam Negeri Sumatera Utara, 2019. http://repository.uinsu.ac.id/6135/.

Prabowo, Sugeng Listyo. Perencanaan pembelajaran pada bidang studi, bidang studi tematik, muatan lokal, kecakapan hidup, bimbingan dan konseling. Malang: UIN-Maliki Press, $2010 . \quad \mathrm{http} / / /$ repository.uinmalang.ac.id/1616/.

Sutiah. Pengembangan Kurikulum PAI Teori Dan Aplikasinya. Malang: NLC, 2020.

Trianingsih, Rima. "Pengantar Praktik Mendidik Anak Usia Sekolah Dasar." Al Ibtida: Jurnal Pendidikan Guru MI 3, no. 2 (29 Oktober 2016): 197-211. https://doi.org/10.24235/al.ibtida.snj. v3i2.880. 
Usman, Usman. 'Pemenang Di Atas Panggung Melalui Mahir Public Speaking." Komunikasiana: Journal of Communication Studies 1, no. 1 (30 Oktober 2018). https://doi.org/10.24014/kjcs.v1i1.62 86.

Utami, Christina Dwi Kartika Budi. "Pengaruh Metode Belajar Aktif Model Pengajaran Terarah Dalam Meningkatkan Prestasi Belajar IPS Perjuangan Melawan Penjajah Pada Siswa Kelas V SDN Bringinbendo 2 Kabupaten Sidoarjo." Jurnal Refleksi Pembelajaran (JRP) 4, no. 1 (28 Februari 2019): 14-22.

Yamin, Muhammad, Tobari Tobari, dan Missriani Missriani. "Manajemen Sarana Dan Prasarana Dalam Meningkatkan Hasil Belajar Siswa Di SD IT Kautsar Ilmi Tanjung Raja." Jurnal Intelektualita: Keislaman, Sosial Dan Sains 9, no. 1 (11 April 2020): 139-48. https://doi.org/10.19109/intelektualita .v9i1.5585.

Yusuf, Alfiyan. "Metode Pembelajaran Saintifik Dalam Pengajaran PAI Kelas XI di SMA Windu Wacana Kota Cirebon." Skripsi, IAIBBC, 2020.

http://repository.bungabangsacirebon. ac.id/xmlui/handle/123456789/409.

Zaini, Herman. "Karakteristik Kurikulum 2013 Dan Kurikulum Tingkat Satuan Pendidikan (KTSP)." El-Idare: Jurnal Manajemen Pendidikan Islam 1, no. 01 (2015): 15-31. 